\title{
The Tyranny of Proximity: Power and Mobility in Colonial Cambodia, 1863-1954
}

\author{
Penny Edwards
}

Often typecast as sedentary and static in Western writings, Cambodians have long been on the move. This article explores the misrepresentation of such mobility in colonial narratives, and contrasts the stereotype of the static Khmer with the mobilization of recruits in the First World War, the activities of protesters in Cambodia and political devices like the Royal Tour.

\author{
The administration has organised city and country \\ Stones and pebbles have been pounded and piled \\ Ruts have been raised high to make roads \\ From the city to all the provinces. \\ Every stream and creek has a bridge, \\ Little and big, hundreds and thousands of bridges, \\ Solid as a rock, cars roar over them \\ Thousands of elephants can tromp over them \\ They've never broken. \\ Okna Sann, $1928^{1}$
}

Topography displays no favourites: North's as near as West,

More delicate than the historians' are the Map-maker's colours.

Elizabeth Bishop, 'The Map'2

In 1885, the myth of a colonial pax Franca in Cambodia was shattered by the Protectorate's brutal response to an uprising led by Prince Norodom Sivutha against a new Convention forced upon his uncle King Norodom at gunpoint, which stripped the king and his constituency in the Court of virtually all fiscal and administrative power. Some 4,000 French and Vietnamese troops fanned out across Cambodia, inciting 'fierce hatred' with what one French official described as a 'regime of the sword'. Houses were pillaged, temples looted, and civilians murdered and raped. Thousands of farmers uprooted their families and livestock, taking refuge in the wooded hinterland and along

Penny Edwards is a Research Fellow at the Centre for Cross-Cultural Research at the Australian National University. Her e-mail contact is Penny.Edwards@anu.edu.au. I am grateful to the National Archives of Cambodia for permission to reproduce the two photographs in this article.

1 Oknya Sann, 'Secdey priepbi srok bidaem ning aelow' [A comparison between our country formerly and now], Srok Khmer, 7 (Jan. 1928): 5.

2 Elizabeth Bishop, 'The Map' (1946), www.poetryconnect.net/poets/Elizabeth_Bishop/65 
the Siamese border. They fled from forced both conscription by rebel chiefs and from the colonial troops who were requisitioning their cattle, carts and boats, and treating all peasants as potential or actual armed insurgents. ${ }^{3}$

Both those who took up arms against the French and those who fled from approaching troops were demonstrating the most rudimentary of human skills: the art of mobility. Also on the move were those Cambodians working as trackers, infantry-men and interpreters on these military expeditions, some of whom had gained prior experience as guides and translators on earlier mapping missions. Meanwhile, a number of Cambodians from the colonial capital of Phnom Penh and such provinces as Battambang (then still under Siamese control) were sailing to France in the company of the grand doyen of Indochinese mapping, Auguste Pavie, to enroll at a new École Coloniale, established by Pavie and others in Paris to reward indigenous loyalty. After the violence subsided, we can assume that members of the Cambodian Sangha (Buddhist monkhood) resumed journeys to Siam in search of learning and Buddhist manuscripts. During hostilities, some of Cambodia's more renowned spiritual healers may also have travelled to tend to the sick and wounded.

Cambodian histories of mobility also resonated in material culture, notably carpentry, architecture and ornamentation. Among all the despair evinced by Europeans at the 'disappearance' of Cambodian arts in the first decades of the Protectorate, ox-carts and boats attracted continued recognition and admiration for their graceful symmetry and detailed woodwork. As we shall see, the ubiquitous sala, a roofed shelter that variously functioned as a way-station for travellers and a communal meeting hall, also attracted much comment. Centuries of displacement saw power and status vested in both portable ceremonial items (such as intricate silverware, ritual vessels and regalia) and human constellations of kin and clientele. ${ }^{4}$ The possession of numerous wives and children; the maintenance of dancing corps, artists and orchestras; and the ability to mobilize large numbers of people for corvée labour and military service were all indicators of an official's power. Indeed, the longstanding importance of people as political and economic capital made Cambodians as adept at mobilizing as other peoples in Southeast Asia. This history of movement would find a tragic echo, over a century after the establishment of the Protectorate, in the mass emptying of Phnom Penh and other cities by Khmer Rouge troops in 1975.

These indicators of indigenous mobility were subsumed in colonial discourses on Cambodia. As colonial administrators travelled through the Protectorate - by boat, horse-drawn carriage, automobile, cyclo-pousse and train - they tended to perceive a world of stasis where the only thing on the move was French government and power, and its modernizing project. Unsurprisingly, the colonized were the object of such travel narratives and their pictographic, photographic or plastic equivalents, and appeared as little more than snapshots of time and place whose own mobility was seldom a point of observation. Indeed, Cambodians were commonly viewed as people trapped in alterior

3 Anonymous, 'Le Cambodge', Revue Indo-Chinoise [henceforth RI] (1893): 158. The quotation is from Archives d'Outre-Mer (AOM) INDO, GGI 10042, Résident Général of Cambodia to Governor of Cochinchina, 1 July 1886.

4 Benedict Anderson, Language and power: Exploring political cultures in Indonesia (Ithaca: Cornell University Press, 1990), p. 43. 
time and suspended in motion. This mirage of an immobile population accentuated the notion of colonizers as liberators capable of bringing their charges out of a feudal past and into an imperial present. The arts administrator Georges Groslier, for example, described Cambodians as 'immobilized for centuries'. In this version of history, it was the French Protectorate which freed Cambodians from stasis, so that they were 'suddenly seized with an excessive wanderlust [and] began in the space of ten years, to tour around the country and to travel through it'. ${ }^{5}$ These public fictions belied urgent preoccupations in internal reports with both the movement of Cambodians across geographic and cultural borders and the influx of culturally corrupting influences. Thus, as the late art historian Ingrid Muan has shown, Groslier's euphoria was tempered by his concern at the subversive potential of roads as non-discriminating arteries which brought cheap trinkets and unwanted influences into the cultural sanctum of le Cambodge, thus disrupting colonial schemes to trammel aesthetic production and consumption back in time to Angkorean ornamental templates. ${ }^{6}$

Next to such prescriptions for the fixity, shape and scope of Khmer culture, monuments such as a waxwork 'still-life' of Cambodian Buddhists displayed in Paris in the Exposition Coloniale Internationale of 1931 functioned as totems of the supposed malleability and inertia of the colonized. From Pavie's mapping mission of Cambodia in 1885 to stage-managed pro-Vichy marches in Phnom Penh in 1944, this colonial iconography of stasis and the parallel containment and re-routing of indigenous traffic emerged as key trends in the construction of what I have elsewhere described, borrowing from the work of Thongchai Winichakul, as the 'geo-cultural body' of Cambodia. ${ }^{7}$ This freeze-frame of indigenous life jars with numerous testaments to a Khmer world in motion. Such legacies include a 1909 poetic travelogue of Angkor by the celebrated writer Suttantprija In; letters written on the outbreak of the First World War by Khmer princes travelling by train in France; the memoir of Huot Tath, a leading reformist monk who visited Hanoi in the 1920s; and rare footage by the French photographer Léon de Busy taken in Cambodia in the late 1920s. ${ }^{8}$

Monks, who had long been part of a peripatetic network stretching from Sri Lanka, Burma and Siam in the west to southern China and the Shan States in the northwest, were a natural focus of colonial efforts to curtail movement across Cambodia's borders. ${ }^{9}$ Despite such measures, indigenous movement continued throughout the colonial period. Rural dwellers bypassed colonial provincial officers, taking complaints directly to the king in the capital. Monks from Svay Rieng and other provinces presented petitions

5 Ingrid Muan, 'Citing Angkor: The Cambodian arts in the age of restoration' (Ph.D. diss., Columbia University, 2001), p. 16, quoting George Groslier, 'La fin d'un art', Revue des Arts Asiatiques, 6, 3 (1929-30): 180.

6 Muan, 'Citing Angkor', p. 18.

7 Penny Edwards, 'Cambodge: The cultivation of a nation, 1860-1945' (Ph.D. diss., Monash University, 1999).

8 Oknya Suttantaprija's account has been published as Suttantaprija in, Nirieh Nokor Vat/Un pélérinage à Angkor en 1909 (Phnom Penh: Buddhist Institute, 1969); it first appeared in Kambuja Surya newspaper in 1934.

9 A short history of the Buddhist Institute, ed. and tr. Penny Edwards (Phnom Penh: Buddhist Institute, 2005), pp. 10-11, 13-39. 
concerning the effects of modernization to chief monks in Phnom Penh and elsewhere, while news and entertainment merged in the repertoire of wandering minstrels.

Such physical, artistic and spiritual peregrinations repudiated the cultural logic of precisely those borders that figures like Pavie were so intent on defining. At worst, these boundary-crossings threatened to denaturalize the geographic and political construct of Cambodia and so to reveal the Protectorate as phantasm. ${ }^{10}$ France's defeat by Prussia in 1870 heightened the need to propagate the colonial myth of peace, stability and Gallic victory to Metropolitan audiences, thus intensifying interest in depicting the Cambodians as inherently sedentary and literally fixed in their traditions. The psychological desire to seal Cambodia off from what was perceived as an unruly and chaotic past in European narratives about its history after the abandonment of Angkor as the capital, together with socio-economic concerns to direct the movement of people and goods and political preoccupations with managing flows in ideas, inflected a range of colonial practices and policies ranging from cartography and urban planning to travel restrictions on the Sangha. Within these schemata, new technologies acclaimed in Europe for their democratizing effect - such as the telephone and telegraph, often applauded for overcoming the tyranny of distance - underpinned a new tyranny of proximity by allowing the state and its agents closer scrutiny of its subjects, while broadening the reach of government directives that might otherwise have circulated in Phnom Penh alone. In other words, typewriters, roads and the vehicles that plied them brought countless individuals across Cambodia within a colonial grid of taxation, identity cards, corvée labour and law enforcement.

Despite their own status as the internal exiles of empire, many of whom rotated from post to post and rarely returned to the Metropole, French administrators were largely considered to be 'rooted' in their civilization, moving in the 'right' direction - unless they happened to gravitate towards Cambodian society, dress or kinship, in which case they were often deemed to be challenging the laws of racial gravity and descending into decadence. ${ }^{11}$ Cambodians, by contrast, were seen as time-travellers, albeit ones stuck in a degenerate, medieval groove. As one of many twelfth- and thirteenth-century stone structures that had survived, Angkor gained particular salience in European narratives as a fortress of time-stood-still. In what follows, I examine how these notions of immobility played out around several key sites: the sala, the road in its material and symbolic forms, the military and the royal tour.

\section{Sites of passage: the sala}

As Arjun Appadurai has argued, '[n] atives, people confined to and by the places to which they belong, groups unsullied by contact with a larger world, have probably never existed'. If, following James Clifford's lead, we focus on circuits and itineraries, we can read Cambodian society as highly mobile. ${ }^{12}$ Across Cambodia, ample evidence of circuits

10 Ana Maria Alonso, 'The politics of space, time and substance: State formation, nationalism and ethnicity', Annual Review of Anthropology, 23 (1994): 379-405.

11 For more on this theme, see Penny Edwards, 'On home ground: Settling land and domesticating difference in the "non-settler" colonies of Burma and Cambodia', Journal of Colonialism and Colonial History, 4, 3 (2003).

12 James T. Clifford, Routes: Travel and translation in the late twentieth century (Cambridge, MA and London: Harvard University Press, 1997). The quotation is from Arjun Appadurai, 'Putting hierarchy in its place', Cultural Anthropology, 3, 1 (1988): 39. 
of travel and exchange existed in the widespread presence of sala. A raised and roofed platform, typically built of thatch and leaves at roadside or riverside locations and of timber and tiles on temple grounds, the sala was at once the hub of the village, a place of gathering and of passing on news, and a way-station. Roadside sala sheltered people and livestock from the elements and mirrored two other significant structures, both known as khtum: the shelters from which farmers guarded their crops, and shrines to tree spirits and territorial divinities known as neak ta. The role of all three such structures in Khmer folktales and temple murals as the staging grounds for key events indicates their longstanding presence in cultural life. While the term sala appears in a variety of compounds, denoting schools (sala rien), law-courts (sala ktiy) and monastic dining halls (sala chan), this discussion will focus on the structure built primarily as a shelter for travellers.

As Europeans explored and surveyed Cambodia, they relied precisely on this latter function. Reporting on a 1904 visit to Sisophon, a western district then still under Siamese control, Pierre de la Brosse defined the sala as 'a house for foreigners' and was so impressed by his overnight stay in one such 'comfortable wooden house' that he recommended it 'as a model for all buildings of this type built by our administration in Indochina'. ${ }^{13}$ Soon afterward, in what may have been one of a series of surveys of sala along main arterial routes, Protectorate employees drew up a crude map of those found between Phnom Penh and Kampot, and slated the best-appointed of such structures for refurbishment as way-stations for colonial civil servants. At around this juncture, the naval officer and amateur archaeologist Étienne Lunet de Lajonquière concluded from his experiences of sleeping rough in Battambang that the 'rustic dwellings of Cambodians' were 'rigorously closed' to all foreigners yet noted the near ubiquitous presence - at the entrance to every village, and especially in the vicinity of temples - of a 'kind of hangar called sala, designed for travellers'. ${ }^{14}$

This doublespeak rendered the sala, a site of recognized hospitality, as a symbol of Khmer inhospitality. The apparent indigenous reluctance to invite Europeans into Cambodian homes was thus rendered not as an exercise of sovereignty, dignity or resistance, but as a cultural fault. The abuse of the privileges of a sala by Europeans received less public attention. In 1925 Paul Collard, who compared the passivity of Cambodians to that of their buffaloes, described the sala as a house of gathering, built as a shelter for people 'whom the exigencies of life or service had thrown on long journeys: businessmen, farmers, officials of the Protectorate or of the Palace, on transfer, or the bearers of orders to indigenous authorities'. By the early twentieth century, 'sala' was adopted into colonial patois as the term for 'guest house' or 'hotel'. The first hotel at Angkor, styled after the 'bungalow' of British India, was officially called 'Sala d'Angkor'. ${ }^{15}$

13 Pierre de la Brosse, 'Dans les provinces cambodgiennes rétrocédees (I)', RI (1907): 1156.

14 Étienne Lunet de Lajonquière, 'La rétrocession des provinces cambodgiennes', Bulletin du Comité de l'Asie Française, 8, 87 (1908): 227. The survey is in National Archives of Cambodia (NAC), RSC 10003, 'État des sala le long de la route de Phnom Penh à Kampot'.

15 See Étienne Lunet de Lajonquière, 'Cambodge', Bulletin de l'École Française d'Extrême Orient, 8 (1908): 420; and Félicien Challaye, 'Angkor', La Revue de Paris, 29, 8 (April 1922): 787. The quotation is from Paul Collard, Cambodge et Cambodgiens (Paris: Société d'Éditions Géographiques, Maritimes et Coloniales, 1925), p. 63. 
These many evaluations of the sala undermined colonial observations about the sedentary nature of Cambodians. Noting that the latter did sometimes (though rarely) make long journeys, Lunet de Lajonquière characterized even these movements as prone to a certain paralysis: they were always in the same direction, along the same routes, for fulfilment of seasonal obligations such as cutting firewood, fishing in certain swamps, driving herds to pasture, and so forth. These upheavals 'never take them remotely near the large centres, with which they have hardly any relations and where they only have the opportunity to come into contact with people from neighbouring srok [districts]'. This fixity, he argued, explained why 'the mass of Cambodians have not yet come to embrace the idea of unity in the Kingdom' and also underscored the impossibility of ever creating 'public opinion'. ${ }^{16}$ In other words, it was not that Cambodians did not move, but rather that they were moving in the wrong direction.

That wayward movement was noted later that year when, soon after Bangkok's retrocession of Battambang to the French in 1907, whole villages decamped and, together with monks, made the long trek across the Dangrek Mountains on the northwestern frontier, abandoning Cambodia for Siam. Official explanations for the emigration blamed it on the Siamese, again robbing Cambodians of agency for their actions. Historian John Tully, in his revealing thesis on the French Protectorate, challenges this view. Noting that the movement continued after an armed uprising and the arrest of its purported leader, he relates how 'this peculiar form of resistance disturbed and puzzled the French'. Peasants, he continues, usually 'adhere tenaciously to their villages and plots of land, and the tradition-bound Cambodians were no different to others in this respect'. ${ }^{17}$ But were they?

For centuries, the story of Cambodia had been one of movement: the capture, displacement and resettlement of populations; the raising of armies; flight from invading troops; and the abandoning of cities and villages. As in many other Southeast Asian societies, the noted proclivity of Cambodians for staying in 'their place' was not so much a geographical as an anthropological state, tied up with social station within patronclient and kinship networks, referred to in Khmer as ksae (strings). Across most of Cambodia, these ksae remained in place, but when they were forcibly dislodged - as in Battambang - it was clear that Cambodians were not averse to mobilizing in support of their patrons. ${ }^{18}$ The emigration across the borders to Siam was not the only form of mass movement accompanying the retrocession. In July 1907, some 2,000 Cambodians gathered before the office of France's representative in Battambang and demanded that he telegraph Bangkok to request the province's exclusion from the retrocession treaty. For months, terrified Cambodian families moved upriver, fleeing the turbulence of the Tonle Sap for the safer waters of the Bassac and Phnom Penh. ${ }^{19}$ However, even when tranquillity was allegedly restored by the arrival of French officials and troops, and despite the affordability and ease of river transport, only a handful of people from the

16 Lunet de Lajonquière, 'Rétrocession des provinces cambodgiennes', pp. 227-8.

17 John Tully, 'Cambodia in Sisowath's reign' (Ph.D. diss., Monash University, 1993), pp. 98-9, 138-42; quotation from p. 139.

18 Pierre de la Brosse, 'Le territoire de Battambang: Aperçus politiques', RI (1907): 1235.

19 Pierre de la Brosse, 'La rétrocession des anciennes provinces cambodgiennes', RI (1907): $1088,1091$. 
pacified province of Battambang travelled to Phnom Penh, the capital of their new 'motherland'. ${ }^{20}$

\section{Labours of love? Road-building in colonial Cambodia}

New administrative policies enacted in Siam and Cambodia during the late nineteenth and early twentieth centuries sought to attenuate longstanding 'galactic' arrangements of power, and to strengthen central government through the establishment of tighter controls over outlying regions. ${ }^{21}$ Roads were critical in fragmenting and decentering pre-existing power bases by bringing such regions into new circuits of traffic and exchange whose hub was the colonial capital. The consolidation of colonial power in Cambodia coincided with the golden age of cartography, an explosion of interest in geography in France, and a communications revolution in Europe and North America that commenced with the invention of the telephone in 1876 and encompassed the wireless, telegraph, X-ray, cinema, bicycle, automobile and aeroplane. This period of intense technological turmoil, as Stephen Kern has shown, affirmed a plurality of time and space, and its social ramifications have been associated with the levelling of aristocratic society and the ascendance of plural democracy. ${ }^{22}$ In the colonial arena, identical technologies translated into different codes of meaning. The liberating road taking peasants to markets also took tax inspectors to peasants. A network of new roads and modes of transport, telegraph wires and telephones replaced what is often referred to as the 'tyranny of distance' with a new tyranny of proximity which extended the reach of the state in a myriad ways, from colonial armies despatched along new routes to crush dissent, to royal-colonial tours travelling the same swift roads to rally rural goodwill, officials in their automobiles travelling from provincial offices to outlying villages to collect taxes, and telegraph wires cabling provincial chiefs about new calls for corvée labour teams to lay new roads. While paved roads were commonly referred to as 'routes of penetration' in colonial correspondence, they routinely bypassed vast tracts of the Cambodian countryside, facilitating communication between colonial centres while heightening the distance between officials in their automobiles and villagers in ox-carts.

Until the turn of the century, Cochinchina provided the reference point for most colonial journeys into Cambodia. It was in Saigon that the great explorers, scholarofficials and lesser luminaries who staffed France's expanding empire began their Cambodian odysseys. By boat they travelled up-river to the landing point of Kompong Luong, and from there made the few-mile trek across land to Oudong, which remained the seat of royal power until the establishment of Phnom Penh as the capital in 1866. From 1872 onward, the Compagnie des Messageries Fluviales (River Transport Company, CMF) ran a regular steam-boat service from Saigon to Phnom Penh; the journey took 36 hours. ${ }^{23}$ Rivers and waterways provided the main communication routes, ensuring that even those administrators who ventured or were stationed far from the capital were largely ignorant of happenings on dry land. Drawn from the navy,

20 Lunet de Lajonquière, 'Rétrocession des provinces cambodgiennes', pp. 227-8.

21 Anne Hansen, 'Ways of the world: Moral discernment and narrative ethics in a Cambodian Buddhist text' (Ph.D. diss., Harvard University, 2000), pp. 3-4.

22 Stephen Kern, The culture of time and space 1890-1918 (Cambridge: Harvard University Press, 1983).

23 Albert Tissandier, Cambodge et Java: Ruines khmeres et javanaises (Paris: G. Masson, 1896), p. 4. 
the first wave of French administrators in Cambodia and Cochinchina 'focused all their attention on improving water routes, thinking it useless to busy themselves with land routes'; a typical tour of inspection stopped at the riverbank. In 1879, Governor of Cochinchina Charles Le Myre de Vilers ordered the construction of two guest-houses in MỹTho and Phnom Penh so that European visitors 'could get to know the intérieur of the colony'. ${ }^{24}$

Colonial transport networks helped to redirect trade traffic on Indochinese routes. Co-ordination of a new railway from Saigon to Mỹ Tho with a new CMF steamer service from the latter town to Phnom Penh, operative in 1896, tightened links between Cochinchina and Cambodia. By 1889, the CMF ran weekly steamers to Battambang, which reoriented the province's exports from Bangkok to Cochinchina even before the retrocession, and a weekly CMF service from Phnom Penh to Kratie and Sambor welded Cambodia's northern regions closer to the central administration. ${ }^{25}$

However, Cambodia still had 'no roads worthy of the name', or so declared one publication in 1889. Those from the precolonial era had disappeared or become impractical. Now that the Sivutha rebellion had been squashed, road construction was deemed a priority for security and commercial prosperity. ${ }^{26}$ From $1883-85$, the explorer Auguste Pavie conducted numerous and extensive mapping tours of the Cambodian hinterland, including Kompong Cham and the frontier with Tây Ninh in Cochinchina. In 1884, when a fellow surveyor was tasked with mapping Kompong Luong and the environs of Oudong, he reported that poor roads and transport prevented him from journeying further into the sparsely populated interior. Reporting to the French representative in Cambodia, Pavie stressed the strong desire of rural Cambodians in these regions for roads, so that they might travel easily between villages. 'They are ready to start whenever you want', he continued. 'We could use this goodwill to create by-roads in the intérieur of the country as soon as possible, and to have roads made at little cost. ${ }^{27}$

Roads, of course, did not have to appear on a map to exist. In the 1890s, when visiting Battambang, Prince Henri-Philippe d'Orléans travelled by a road 'which had only been used by one or two Europeans and does not appear on any map ... [b]ut [which] is very much used by natives.... Ten years later, the administrator Pierre de la Brosse noted the dire state of roads in Battambang. Envisaging Sisophon's emergence as

24 Quotations from Charles Le Myre de Vilers, 'Preface', in Maurice Rondet-Saint, Choses de l'Indochine contemporaine, 2nd edn (Paris: Plon, 1916), p. xxii. An example of an official tour of inspection is the following comment. 'Last Wednesday I journeyed along the banks of the Great River as far as Krouc Chmar', wrote the French Representative in Cambodia to the Governor of Cochinchina in September 1884, 'and noticed that everywhere was calm' (AOM INDO, GGI 12504, Rep. of Protectorate of Cambodia to Governor of Cochinchina, 26 Sept. 1884).

25 Tissandier, Cambodge et Java, mentions the railway-steamer connection (p. 4). On the CMF's expansion see Les colonies françaises III: Colonies et protectorats de l'Indochine, ed. Louis Henrique (Paris: Maison Quantin, 1889), pp. 120-1, 174. Battambang had previously exported most of its produce overland to Bangkok; after the CMF was set up, large quantities of rice, dried fish, animal skins, spices, silk and ivory were shipped eastward to Cochinchina.

26 Henrique, Colonies françaises, pp. 120-1, 174.

27 Representative of the Protectorate to Governor of Cochinchina, 26 Sept. 1884. On Pavie's work see also AOM INDO, GGI 12504, Representative of the Protectorate to Governor of Cochinchina, 26 Aug. 1884 in the same file. The 1884 surveyor's report is in GGI 11058, M. Martin to Chef de Cabinet of the Governor of Cochinchina, 9 Dec. 1884. 
a regional transport hub, he called for road repairs and the laying of new routes, but predicted maintenance problems in these 'sparsely populated' parts of Indochina, where people 'travel little'. ${ }^{28}$

By 1900, there were 50 kilometres of surfaced roads in Cambodia, but no cars to ply them. The lack of roads linking the new colonial capital of Phnom Penh to the intérieur necessitated elaborate detours via Cochinchina to reach such Cambodian provinces as Takeo and Kampot. ${ }^{29}$ In 1903, Résident Supérieur (the top-ranking French official in Cambodia) Henri Félix de Lamothe began a tour of the Cambodian hinterland one Monday on a steamboat from Phnom Penh to Châu Đốc in Cochinchina. On Tuesday, he boarded a rowing boat on the Châu Đốc River, and four hours later switched to a smaller vessel which navigated the myriad, meandering waterways through Châu Đốc to Takeo. Here he met with Cambodian officials, militia and representatives of the local Chinese and Vietnamese communities. To reach the neighbouring province of Kampot, Lamothe had to return to Châu Đốc. He left Takeo by boat on Wednesday, reached Hà Tiên (in Cochinchina) on Thursday morning, set sail for Kampot at dawn on Friday and arrived at noon. After two days of festivities, Lamothe and his team departed for Phnom Penh. A flotilla of pirogues carrying Cambodian provincial governors escorted them down the Kampot River and out to sea. Banner-waving Cambodians thronged the riverbanks, and a Cambodian customs officer saluted the Tricolor. After breaking his journey again in Hà Tiên and Châu Đốc, Lamothe reached Phnom Penh on Wednesday morning. ${ }^{30}$

This narrative reveals how, at the turn of the century, the separate administrative spheres of Cochinchina and Cambodia were still intertwined by the exigencies of transport to form a messy-edged colonial cosmos. It also illuminates the restricted vision of French administrators, whose supposed inland tours often took them no further than waterways and riverbanks. Members of the small, mobile colonial Khmer elite such as Thiounn Sambath (c. 1864-1950) and Son Diep (c. 1855-1934), their horizons similarly restricted, would have experienced these journeys in and around Cambodia and the adjacent Khmer-inhabited areas of Cochinchina as pathways through a predominantly Khmer cosmos whose centre of gravity was the royal and colonial capital of Phnom Penh, not Saigon. In 1904, prior to being transferred to Cambodia from a prefect's post in Cochinchina, Son Diep declared his intention to 'make every effort to get the [royal] Council of Ministers to propose projects beneficial to this country and to the French Protectorate, such as building roads across the huge uninhabited regions' ${ }^{31}$

Cambodians living outside of Phnom Penh, for their part, would have had little notion of the administrative capital, or indeed of the newly minted, modern cartographic shape of Cambodia. Forty years after the establishment of the Protectorate, the central administration must have appeared as little more than a water-borne mirage, melting

28 Pierre de la Brosse, 'Le territoire de Battambang: Notes économiques', RI (1907): 1330. The prince's comment is in Henri-Ph. d'Orléans, L'âme du voyageur (Paris: Calmann-Lévy, 1902), pp. 296-7. The road's popularity was due to its linkage to Chantaboun in Thailand and recently opened gem mines at Pailin.

29 Groslier, 'Fin d'un art', pp. 179-80; Muan, 'Citing Angkor', p. 16. The 147-kilometre road from Phnom Penh to Kampot was nearly finished, but the administration was still looking for funds to complete paving. 30 A. Raquez, 'Cambodge: Notes du voyage', RI (1903): 953-6.

31 AOM FP, APC 46 1, Son Diep, Tri-Phu [Prefect] of Sóc Trăng, to Auguste Pavie, 15 May 1904. 
back into the water as quickly as it appeared. The above river-bound scenario of people and customs officers waving at their administrators from dry land is replicated almost exactly in the celebrated Khmer poet Suttantprija In's account of a boat journey by French and Khmer officials to Angkor several years later. ${ }^{32}$ The retrocession of Battambang, which was practically 'cut off' from Cambodia for six months each year during the dry season, heightened the need for an expanded road and rail network. ${ }^{33}$ In ensuing decades, new communication routes became of increased importance for the transport and trade of raw materials, the deployment of troops and the re-orientation of Cambodian monastic circuits away from Siam and towards Phnom Penh.

Maps, local governance and roadworks came together in 1908 when the Protectorate reformed local administrations by introducing a 'khum' ('commune' in French) in keeping with the 'artificial proto-villages' established by colonial authorities elsewhere in Southeast Asia. ${ }^{34}$ Modelled on the rural commune system in France, this innovation was partly designed to extend the horizons of rural identity beyond Cambodia's self-contained villages to the wider geographic and administrative entity of the emergent colonial nation-state. From the newly-formed khum, it was only one step on the Protectorate's map to the provincial capital, and after that to Phnom Penh. However, this bureaucratic lexicon did not necessarily remap the rural habitus; from the cradle to the grave, wrote Lunet de Lajonquière in 1908, many Cambodians never crossed the limits of their khum. ${ }^{35}$

The following year, when the Protectorate launched a mass public works programme, the Council of Ministers issued a Khmer circular to explain the benefits that roads would bring to peasants by allowing them to transcend these narrow horizons.

People in the districts must work to create roads so that they can come and go to make a living and transport goods.... If buyers and the makers of goods live far apart, and have no roads to come and go and meet together, how can they trade together? Don't let the people in your districts think that the administration is making roads because the administration needs roads ... make them see how much use they will all get from the administration's roads that they are building. At present Cambodia still has no roads. ... ${ }^{36}$

By encouraging peasants to think in terms of the national advantage of such roads, Minister of War and Education Ponn, who prepared the circular for dissemination to all provincial chiefs, district chiefs and commune officials, hoped to dispel widespread antipathy to the ten days of annual corvée labour.

Monopolised by the colonial administration, the roads - like the telegraph and telephone lines - consolidated ideas of community among an elite group of privileged

32 Suttantiprija, Nirieh Nokorvat, pp. 8-11, 16-17, 40-1.

33 De la Brosse, 'Rétrocession des anciennes provinces cambodgiennes', p. 1084.

34 Chheat Sreang, 'The Cambodian khum from 1897 to 1919 and its contemporary relevance' (M.A. thesis, Royal University of Phnom Penh, 2004). For the broader Southeast Asian context see Robert Elson, 'International commerce, the state and society: Economic and social change', in Cambridge history of Southeast Asia, ed. Nicholas Tarling, vol. II (New York: Cambridge University Press, 1992), pp. 165-6.

35 Lunet de Lajonquière, 'Rétrocession des provinces cambodgiennes', pp. 227-8.

36 AOM INDO, RSC 466, Conseil des Ministres No. 103, 'Preahkoronajie ammcah jiwit le tboung drong preareicanunia prompung Sa Dra' (undated circular pursuant to meeting of 3 Sept. 1909). 
users, while widening the gap between colonial officials and the general populace. A random sample of telegraph traffic between French administrators in the Protectorate and the Metropole in 1904 indicates an overwhelming preoccupation with European news to the virtual exclusion of Cambodian affairs. The scant correspondence on Cambodia focused on a colonial world of administrative promotions and status symbols, such as the new pair of grey horses to pull the Résident's carriages. ${ }^{37}$ As the colonial bureaucracy expanded, Résidents were increasingly tied to their desks. The level of reporting from Cambodian provinces to Phnom Penh, Saigon, Hanoi and Paris rose exponentially with the provision of typewriters to all Résidences by $1909 .{ }^{38}$

The modernization of Cambodia's transportation created a two-tier system. The introduction of a new centralizing vocabulary of state administration; the collapsing of multiple loci of religious belonging, royal authority and commercial activity into the new colonial capital of Phnom Penh; and attempts to redirect economic transactions and geocultural identifications through the laying of new communication routes created not one holistic system of movement, but parallel realms of transit. This duality was not unique to Cambodia, and is nicely captured by Joseph Conrad. En route to Kurtz's hideout, Marlow finds 'a stamped-in network of paths spreading over the land, through ... grass ... up and down stony hills'. Apparently oblivious to the genesis of these grooves, a white man in uniform, camping across one path, declares to Marlow that he is looking after 'the road'. 39

The ancient roads of the city of Angkor had spread out in straight lines from the central hub of Angkor Wat to the surrounding temples and, although their traces were still intact, were now criss-crossed by new paths and tracks. ${ }^{40}$ In 1907, more than 200 people visited Angkor, and several leading travel agencies began including the temple in their world tours; to improve tourist access and facilities, Lunet de Lajonquière recommended building a new road and a new guesthouse. ${ }^{41}$ The following year, the Duc du Montpensier started a vogue in driving from Saigon to Angkor, careering up the stairway to Angkor Wat in his automobile. In 1909, Governor-General Antony Klobukowski officially launched new access routes opening up Angkor to 'savants, artists and tourists' come rain or shine, by land or water. ${ }^{42}$ Within the newly framed Angkor Park, construction of new buildings and roads was forbidden, while the movement of people to and through the complex was brought under new scrutiny. Not until 1925 did a French administrator, though declaring himself not overly enamoured of 'native drivers and domestic staff', point out the unfairness of asking Cambodian drivers to pay an entry fee.

37 AOM INDO, RSC 27, Telegram No. 215, 20 Nov. 1904, Résident Supérieur of Cambodia (RSC) to Résidents of Kandal, Kampot, Takeo, Kompong Cham and Pursat; Telegram No 230, 29 Nov. 1904, RSC to Résident of Kompong Cham. The sample is taken from telegrams 120-230 for November 1904.

38 David Chandler, A history of Cambodia, 2nd edn (North Sydney, NSW: Allen and Unwin, 1992), p. 152.

39 Joseph Conrad, Youth, heart of darkness, the end of the tether (London: J. M. Dent and Sons, 1967), pp. 70-1.

40 George Groslier, A l'ombre d'Angkor (Paris: Augustin Challamel, 1916), pp. 153-4, describing the road from Angkor Vat to Banteay Chmar.

41 Lunet de Lajonquière, 'Cambodge', p. 420.

42 Léon de Beylié, Les ruines d'Angkor (Paris: Leroux, 1909); see the dedication on the Frontispiece, and p. 28. The auto trip is mentioned in Bruno Dagens, Angkor: La forêt de pierre (Paris: Gallimard, 1991), pp. 84-5. 
He also observed that it was not only tourists who used the roads around the Park's perimeter, but also the local population - to travel to Siem Reap, transport their goods there, and access roads to other regions. ${ }^{43}$

Within Phnom Penh, urban planners and their overseers paid close attention to the movement and locale of indigenous people. In 1915, for example, considering plans for new shops and public offices, the Municipal Council of Phnom Penh decided that these should be 'put out by the road to Kampot, and next to Stung Meanchey, where establishments of this type are better placed', with their 'many inconveniences, dust, noise, the movement of many natives'. The Council maintained that there is no place for [such things] in the districts which have, over the years, been reserved for Europeans' ${ }^{44}$ The development of new roads conversely tightened links within the French colonial community, speeding access to other towns and Résidents, while placing an even greater distance between the French in their automobiles and the Cambodian peasants in their ox-carts. The motorcar made its debut in Phnom Penh in the first decade of this century. Cambodia's first bus, which ran from Kampot to Phnom Penh, appeared in 1912. In 1914, the capital counted 30 tour cars and five buses, and the entire country had 600 kilometres of surfaced road. ${ }^{45}$ By 1919, a total of 86 vehicles had registered as buses, managed by Chinese and European companies; some covered all the roads in Cambodia, while others specialised in leisure travel from Phnom Penh to Kampot for French holidaymakers. These statistics indicate that only a privileged few enjoyed use of the roads, corroborating Alain Forest's contention that roads in Cambodia were of most benefit to European travellers and Chinese entrepreneurs. ${ }^{46}$

\section{Militarization, protest and mobility}

The birth of Cambodia's colonial road system was twinned by the establishment of a Cambodian militia, founded in 1885 to guard the Résidence in Phnom Penh against both rebel forces and an alienated population. ${ }^{47}$ These two developments also underpinned another travel device given new motion by the Protectorate: the Royal Tour. In August 1885, the Protectorate allocated 500 piastres to Obbareach (Second King) Sisowath, their royal ally in their expeditions against Norodom's nephew Prince Sivutha, for distribution 'in the name of the French government' during a tour of the provinces. This generosity was as much an investment in Sisowath's loyalty as in France's public standing. The following month acting Résident Général Renauld impressed upon the governor of Cochinchina the need to reimburse Sisowath for such travels as a means of winning his loyalty and weaning him further and further away from Norodom. ${ }^{48}$

43 NAC, RSC 8353, Administrateur des Services Civils, Résident of Siem Reap, to RSC, 19 July 1925.

44 NAC, RSC 24127, 'Extrait du registre des déliberations de la Commission Municipale Consultative de la Ville de Phnom Penh, séance du 9 avril 1915'.

45 Groslier, 'Fin d'un art', pp. 179-80; the bus is mentioned in Michel Igout, Phnom Penh then and now (Bangkok: White Lotus, 1991), p. 133.

46 Alain Forest, Le Cambodge et la colonisation française: Histoire d'une colonisation sans heurts (18971920) (Paris: Harmattan, 1980), p. 233. Forest notes that some administrators blamed the success of the 1885 insurgency against the French on the state of the roads.

47 AOM INDO, GGI 10052, Representative General to Governor of Cochinchina, 1 July 1886.

48 AOM INDO, GGI 12661, Representative General par interim to Governor of Cochinchina, 7 Sept. 1885. On the allocation, see the correspondence between these two offices dated 17 and 18 Aug. 1885, in GGI, 12665. 
The expansion of the national militia and the introduction of compulsory military service under King Sisowath (r. 1904-27), gave Cambodians a new sense of both national belonging and national mobility. In November 1910, a soldier in the Cambodian Infantry wrote to Pavie, 'I started work [three days ago] ... military service seems simple enough .... I get along well with my French comrades. ${ }^{39}$ By 1915, Cambodia's colonial army had expanded to a three-company battalion, with a European company stationed in Phnom Penh and two Khmer infantry companies stationed in Battambang and Sisophon. Seventeen detachments of native guards were stationed at French provincial headquarters across the country. ${ }^{50}$

The First World War brought a new phase of indigenous mobility, as hundreds of Cambodians from poor backgrounds were dispatched to French trenches. Pach Chhoeun, a then little-known Khmer Kraom (ethnic Khmer from Cochinchina) in the colonial administration who would emerge as a leading nationalist in the 1930s, was sent to France to interpret for Khmer troops. ${ }^{51}$ While controversy surrounded conscription practices, some members of the elite opted for the battlefield. In August 1914, a month after graduating from the Lycée de Limoges, the eighteen-year-old Prince Sisowath Pinnoret (1895-1919) wrote to the Governor-General's representative in Paris expressing his willingness to serve in the French army. 'I believe I have the physical makings of a soldier', he affirmed. 'Besides, I am sure that my grandfather [Sisowath], who also fought for France, would be happy and proud to see his grandson follow in his footsteps .... Three weeks later, Prince Sisowath Watchayavong (1891-1970) declared his love for France, 'my second country', and his 'duty to fight for her'. The next day, he penned another letter from Caën, having travelled there by train with hundreds of reservists. Brimming with enthusiasm for the journey, the spirit of adventure and the generosity of his fellow travellers, Watchayavong requested permission to enlist. ${ }^{52}$ The following year, on 1 January 1916, three Cambodian conscripts penned their New Year wishes for a good and happy life from Pau, on a locally produced postcard that showed the spruce trio in uniform. (see Figure 1).

In Phnom Penh, Résident Supérieur François Baudoin placed Prince Sisowath Monivong, recently returned from military college in France, in charge of troop recruitment. Subscriptions to a war bond were raised throughout Indochina. King Sisowath called upon 'all people and races of Cambodia' to lend both their money and their lives to France's war. Allegations of foul-play abounded, and it is not unlikely that the war-fund assumed the form of one more tax which, together with the fiction of 'voluntary'

49 AOM IFM 46, APC1 (Illegible) of Phnom Penh to Auguste Pavie, 11th Regiment of the Cambodian Infantry, 20 Nov. 1910; on the reaction to military service see Adrien Pannetier, Notes cambodgiennes: Au coeur du pays Khmer (Paris: Payot, 1921), p. 140.

50 Paul Alinot, Géographie générale de l'Indochine Française (Saigon: Albert Portail, 1915), p. 63.

51 Ben Kiernan, How Pol Pot came to power (London: Zed Books, 1981), pp. 19-20.

52 AOM INDO, GGI 2576, Prince Pinnoret, Lycée de Limoges to M. Capus, Delegate of the Governor General of Indochina (GGI), Paris, 1 Aug. 1914; Prince Watchayavong to GGI Delegate, 21 Aug. (patriotism) and 22 Aug. (request for permission) 1914. It seems that permission was refused: in January 1918 Watchayavong was studying for his Baccalauréat and, with his grandfather Sisowath's support, seeking admission to the École Libre des Sciences Politiques (AOM FM INDO, NF 572, King Sisowath to RSC, 22 Jan. 1918). 


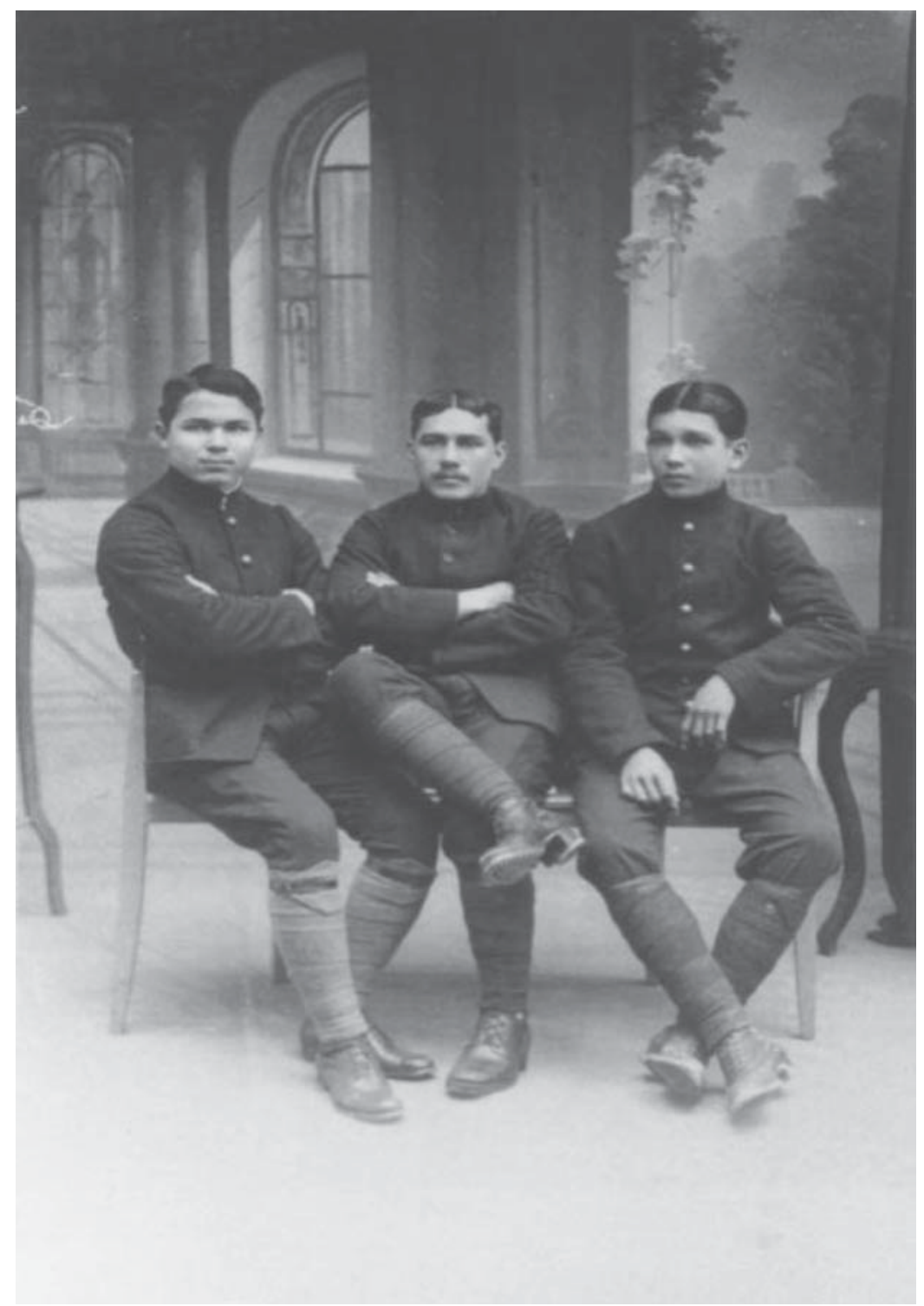

Figure 1 Three Cambodian soldiers, Pau, 1916

Source: National Archives of Cambodia, AQ, 29.

conscription and the increasing demands for corvée labour for the building of roads in Cambodia, pushed anti-colonial feelings to a fever pitch. ${ }^{53}$

53 An anonymous letter containing these allegations, dated 19 Apr. 1917 and attributed to exiled Prince Mayura, is in AOM, INDO, NF 564, RSC note to GGI (undated); Sisowath's proclamation is in 'Proclamation de Sa Majesté à tous Princes, mandarins de la capitale et des provinces et à toute la population de toutes races du Cambodge', RI (1918): 213-14. On Monivong see Areno Iukanthor, Destin d'empire (Paris: Pierre Bossuet, 1935), p. 100. 
Once built, colonial roads were used to take protesting Cambodian villagers to provincial capitals and Phnom Penh in 1915 and 1916, and protesting Cambodian students to the King at Oudong in 1935. Both of these movements travelled new roads, and yet they were partly conducted within pre-colonial power trajectories. In the first example, tens of thousands of Cambodians set out from their villages to the capital, bypassing the colonial administration just as its offices and roads had long bypassed them and seeking a direct audience with the king. In November 1915, 200 corvée labourers from Kompong Cham province, who had been assigned to break rocks for Colonial Route Eleven, took to the streets in protest. They marched to Ksach Kandal, and from there to Phnom Penh, where they demanded to see the king to air their grievances at the corvée scheme. Most peasants were unwilling to work on roads and other such public projects when they could see little immediate benefit to themselves. The unpopularity of the corvée, and the widespread rejection of the Protectorate's attempts to enforce a social contract on such lopsided terms, soon mobilized protesters throughout Cambodia. Two thousand demonstrators from Ksach Kandal marched to Phnom Penh in January 1916, followed by thousands from Bassac and Prey Veng. By late January, an estimated 20,000-40,000 had converged upon Phnom Penh..$^{54}$

Encompassing most major provinces, and involving an estimated 30,000-100,000 people, the protests sparked a new scrutiny of Protectorate policies. Baudoin laid part of the blame on Résidents who continued to remain in their provincial headquarters, ignoring central directives to tour the villages and strike up direct communication with their constituency, preferring instead to deal with the 'natives' through the Cambodian governor. ${ }^{55}$ In 1916, the political benefits of the royal tour were given a new lease of life by mass protests, when tens of thousands of Cambodians reminded the French that the monarch remained for them the ultimate symbol of moral authority. The Protectorate drafted 220 Vietnamese soldiers from Cochinchina to bolster their troops, depleted by deployment in France, and called upon Sisowath to quell the unrest through personal appeals to the population on a royal tour. Significantly, Baudoin did not accompany Sisowath on these visits, fearful that he might become the target of popular anger. ${ }^{56}$

On a visit to Cambodia the following year, the Minister of Colonies complained that Résidents and their administrators did not maintain enough contact with the population, and rarely left the roads travelled by cars. He also asserted that progress had been 'obtained at the expense of the population, exploited beyond all limits. ${ }^{57}$ Despite this

54 AOM FM INDO, NF 28, RSC Report to GGI, 29 Jan. 1916, 'Manifestations hostiles occasionées par des convocations de prestataires contre les impots'. A full account of the protests is in Milton Osborne, 'Peasant politics in Cambodia: The 1916 Affair', Modern Asian Studies, 12, 2 (1978): 217-43; see also Tully, 'Cambodia in Sisowath's reign', pp. 226-35.

55 The Résident of Kompong Cham, for example, who had been advised to tour villages and prepare Cambodians for the forthcoming public works schemes and corvée labour requests, had simply informed the provincial governor, who had told the Meekhum (commune chiefs) 'as per the old practice'; see the 29 Jan. 1916 report 'Manifestations hostiles'.

56 AOM FM INDO, NF 570, GGI to Minister of Colonies, 'Événements du Cambodge en janvier et fevrier 1916', 31 Mar. 1916; the protests as a reminder of the monarch's significance are noted in the 29 Jan. 1916 report 'Manifestations hostiles'.

57 Marie Alexandrine Martin, Cambodia: A shattered society (Berkeley: University of California Press, 1994), p. 39. 
chequered history, the colonial road assumed a central place in colonial mythology as a symbol of white male prowess and an emblem of the inexorable advance of colonialism. This is particularly apparent in La route du plus fort (The road of the fittest) a novel based in 1920s Battambang, by the scholar-official George Groslier. In Groslier's fiction, as in his critical essays, roads operated as the symbol par excellence of the colonial endeavour. Bisecting the barren stretch of land across the 83 kilometres from Sangke to Sisophon, 'the road' is the pride and joy of the novel's chief protagonist Résident Ternier, who predicts its imminent penetration of 'the most isolated regions of northern Cambodia, Laos and northern Siam'. A metaphoric and material divide between the native past and the colonial present, Ternier's road represents the ascendancy of Europe over Asia, structure over chaos, strength over weakness. It is 'young, slim and hard ... as straight and imperative as a fine idea. ... It is order and discipline.' By contrast, Cambodian paths are shrouded in mystery, sculpted from a drowsy past, drilled into the earth by the soft footfall of centuries. Groslier uses the mystique of the road to justify and romanticise corvée labour through the eyes of a Cambodian peasant, who feels nothing but enchantment for the 'naked, burning road for which he and his brothers were requisitioned to break stones'. The road has changed lives and made fortunes. Men once doomed to lifelong bachelorhood now trawl new horizons for a wife; people who never made a cent notch up 20 sales. $^{58}$

Groslier's glowing description of bright-eyed corvée labourers jars with contemporary reports. For many Cambodians, roads became symbols of colonial exploitation. Built by peasants, designed for automobiles and other vehicles but not for pedestrians or animal traffic, roads symbolized not only the connection between city and country, but also the deepening urban-rural disparity. ${ }^{59}$ Particularly notorious was the road to Bokor Mountain in Kampot, built in the early 1920s. The writer Marguerite Duras, who spent part of her childhood in nearby Ream, described the road to Bokor as the "Way of the Cross', dotted with the sun-baked heads of convict labourers buried up to their necks to set an example. ${ }^{60}$ Reports in 1920s Indochinese newspapers accused the Protectorate of reinforcing the road to Bokor with 'human bones', and placed the death toll between 900 and 2,000. Confidential communiqués reported the dead as missing. ${ }^{61}$ A French lawyer argued that a skull-and-crossbones should fly over the Bokor Palace Hotel in place of the Tricolour. ${ }^{62}$ Apparently unconcerned by such accusations, the Cambodian Council of

58 Georges Groslier, La route du plus fort (Paris: Ed. Jaloux, 1925), pp. 144 (isolated regions), 150 (order and discipline, naked burning road). Other examples of such literature include Henry Daguerches, Le Kilomètre 83 (Paris: Calmann Lévy, 1913) and André Malraux, La voie royale (Paris: Bernard Grasset, 1930).

59 Martin, Cambodia: A shattered society, p. 39, citing AOM ASO, NF 202, carton 181, letter of 8 Oct. 1917. 60 Marguerite Duras, interview with Xavière Gauthier, in Duras and Gauthier, Les parleuses (Paris: Éditions de Minuit, 1974); for Duras' literary account of her years in Kampot, see Duras, Un barrage contre la Pacifique (Paris: Éditions Gallimard, 1950).

61 Confidential report of Doctor Duffosé to Résident Supérieur Maspéro, cited in Chhim-Toum dit Pirén to President of the United Nations Committee, 12 Sept. 1946 (document from the Son Ngoc Thanh Papers, Monash University Library). For contemporary reports see A. Fontaine Laporte, 'Les origines de l'affaire Bardez', in La Voix Libre, 9 Jan. 1926 (reprinted from La Libre Cochinchine); La Cloche Fêlée, 26 Jan. 1926; and L'Argus Indochinois, 12 Mar. 1927. See also Tully, 'Cambodia in Sisowath's reign', p. 312.

62 Confidential report of Doctor Duffosé; see also Horace Bleackley, A tour in southern Asia (Indo-China, Malaya, Java, Sumatra and Ceylon 1925-1926 (London: John Lane, 1928), pp. 45-55. 


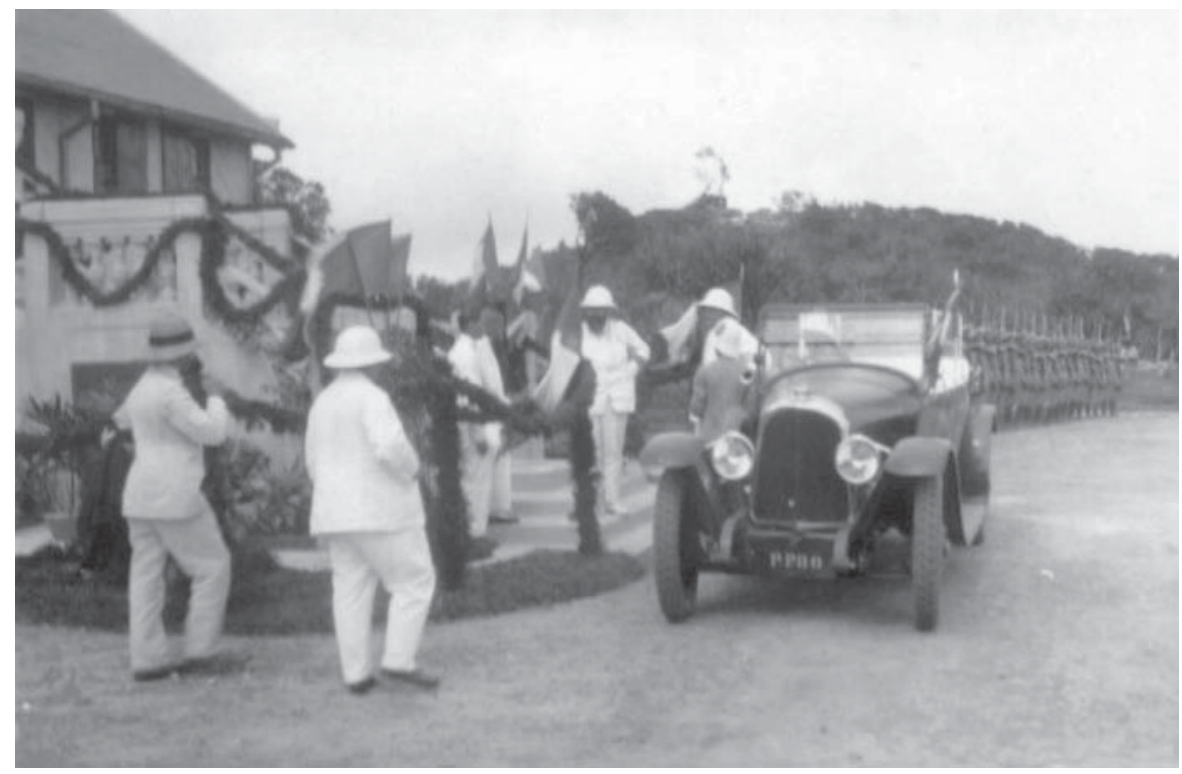

Figure 2 Governor-General Varenne visits Bokor, 1925

Source: National Archives of Cambodia, Phnom Penh.

Ministers lobbied for the speedy completion of Bokor, and seemed more preoccupied with the effects of road expansion on their own properties and plantations. ${ }^{63}$ In 1925 , Indochina Governor-General Alexandre Varenne visited Bokor by car (see Figure 2).

The 1916 protests brought home a sense of unease at the unintended versatility of roads as conduits that could as readily channel popular protest as militia deployments. 'Despite the ... creation of new police posts and frequent tours by the Native Guard', wrote Baudoin in 1922, 'we cannot pretend to ensure complete calm in a country as vast and as poorly populated as Cambodia until the day when as many channels of communication as possible allow an active surveillance and place us in a position to extract effective cooperation from the indigenous authorities'. It was in this context that between 1922-24, Baudoin oversaw the completion of 400 kilometres of paved roads in Cambodia ${ }^{64}$ In 1923, the Protectorate began new road construction as part of a project of 'peaceful penetration' of the sparsely populated, fiercely independent communities of

63 In 1914, one Cambodian wrote to the administration demanding compensation for the loss of his plot of land stretching from the west of the prison in Phnom Penh to the quay of the 'Abattoir Canal', where he had lived for 12 years and which had been devoured by the construction of a new road. In 1917, Oknha Keth, Inspector of Legal Affairs and Cambodian Administration, complained that construction of the road to Kampot had ruined drainage from his coconut plantation; the administration agreed to build ducts along the road. See AOM INDO, RSC 466, Minister of War and Education to Résident Supérieur, letters dated 24 Dec. 1914 and 21 June 1917.

64 David Chandler, 'The assassination of Résident Bardez (1925): A premonition of revolt in colonial Cambodia', in Chandler, Facing the Cambodian past (Chiangmai: Silkworm Books, 1996), p. 146. Baudoin's remark is in AOM INDO, GGI 65502, RSC 'Rapport politique 1922, $3^{\text {ieme }}$ trimestre', 31 Oct. 1922. 
Phnong and Stieng in Cambodia's mountainous northeastern provinces. ${ }^{65}$ In April 1924, the Résident Supérieur reported good progress on these roadworks, claiming that the population was providing 'voluntary labour' and had 'begun to understand the benefits presented by these routes of penetration'. The following year, he reported that Cambodians showed a continued willingness to work on roads, and hill-tribes now understood the benefits of such access routes. ${ }^{66}$

In 1925 as in 1916, the Protectorate's control of traffic flows on these new roads was challenged when 100 peasants took their complaints about punitive new rice taxes raised to offset the costs of the national road programme, to the provincial capital of Kompong Chhnang. Their pleas fell on deaf ears. Later that year, the Résident of Kompong Chhnang, Félix Louis Bardez, travelled to collect taxes in a village about an hour's drive from the provincial capital. He arrived at 8.00 a.m. to find 50-60 village elders waiting for him in the shelter of the sala, with some 500 more assembled in the grounds. By noon, Bardez, the militiaman and his interpreter had been beaten to death. ${ }^{67}$ The one site recognized as a space of hospitality for foreigners had become an execution ground where the poor meted out rough justice to three icons of colonial power: a French Résident, a militiaman, and a Vietnamese interpreter. Following the assassination, the royal tour was once again used to stave off potential unrest. An ageing and ailing Sisowath made what was probably his last tour of the provinces before his death in 1927, visiting Kompong Chhnang to 'proclaim the loyalty of his people to France'. ${ }^{68}$

Living in a remote and poor region and subject to taxes they could ill afford, Baudoin's exhausted, exasperated and largely unrepentant murderers were likely not alone in feeling the tyranny of proximity. When colonial agents travelled those roads, it was usually in search of taxes or labour, and seldom to distribute largesse. The personal largesse and investment in village temples bestowed by notables under the precolonial system of governance were absent from such encounters. Instead, their sweat and taxes were siphoned off into a fiscal and administrative system that favoured urban development and inter-urban communications. Baudoin's successor Fernand Lavit had a passion for roads and instituted a vast network across Cambodia towards Siam, Cochinchina, Annam and Laos. By 1929, Cambodia boasted 2,400 kilometres of surfaced road, 1,840 tourist cars, 820 buses and 270 trucks. Despite the expansion of Phnom Penh's automobile count to 2,930 by 1929 , cars were rarely sighted on the cross-country network of roads established under Baudoin and Lavit. No villages or towns were visible along the road from Kompong Thom to Siem Reap for over 100 kilometres. $^{69}$

65 AOM INDO, GGI 65502, RSC 'Rapport politique 1923, $4^{\text {ième }}$ trimestre’, 24 Jan. 1924.

66 AOM INDO GGI 65502, RSC 'Rapport politique 1924, $1^{\text {er }}$ trimestre', 18 Apr. 1924 and 'Rapport politique $1925,1^{\text {er }}$ trimestre'.

67 Chandler, 'Assassination of Résident Bardez', pp. 148-50.

68 AOM INDO, GGI 65502, RSC 'Rapport politique 1925, $3^{\text {ième }}$ trimestre’, 22 July 1925.

69 Statistics for 1929 are from Groslier, 'Fin d'un art', pp. 179-80; the lack of rural traffic is mentioned in Georges Groslier, Eaux et lumières: Journal de route sur le Mékong cambodgien (Paris: Société d'Éditions Géographiques, Maritimes et Coloniales, 1932), p. 80. One French author quipped regarding a journey from Siem Reap to Kompong Thom that 'if the car had broken down', the passengers would have all 'died of hunger'; Raymond Recouly, A travers l'Indochine et les pays voisins: Pistes, fleuves et jungles (Paris: Éditions de France, 1932), pp. 321-2. 
The 1920s also saw the beginnings of a national rail network; in 1922 work began on a new railway line linking Ream and Kampot to Phnom Penh. The railway line from Bangkok to Aranyaprathet, and a road from Aranyaprathet to Sisophon, were in place by 1929, opening up tour routes from Bangkok to Angkor, Phnom Penh and Saigon. ${ }^{70}$ In 1932, the Phnom Penh-Battambang railway was opened by the governor general of Indochina and Sisowath's successor, King Monivong (r. 1927-41). New settlements of Cambodian houses, with Chinese and Vietnamese restaurants and stalls, soon opened up along the railway. ${ }^{71}$ The railway created new horizons for Monivong's first royal tour since his accession to the throne five years earlier. Designed to shore up the prestige of the monarchy in the aftermath of the coup in Siam, the tour encompassed Kandal, Kompong Chhnang, Pursat, Battambang, Kompong Thom and Kompong Cham. Vast crowds turned out to greet the king, who reportedly glorified France's achievements at every turn, leading the accompanying Résident Supérieur Sylvestre to conclude that their joint voyage had been 'most fruitful in tightening the links between the King and his people' and to plan a follow-up tour of the other main provinces. ${ }^{72}$

In 1936, a group of students protesting the imposition of new fees at the Lycée Sisowath travelled north out of Phnom Penh to seek an audience with Monivong in his summer retreat at Oudong. They were stopped en route and detained for two days by the Surreté; but the protests were successful..$^{73}$ Under Vichy rule, various strategies for regimenting youth 'imbued the royal tour with new theatricality'. ${ }^{74}$ Admiral Jean Decoux, the Governor General of Indochina during World War Two, joined Sihanouk in tours around the Cambodian countryside and to Vietnam. King, Khmers and past grandeur were knit together through such events as the 1941 youth march from Hanoi to Angkor, in which Sihanouk lit an 'Indochinese torch' at Angkor. ${ }^{75}$

\section{Space travel}

David Chandler has highlighted the link between Khmer moral geography and a number of nineteenth-century maps in the form of lists which mapped the Khmer kingdom not as a cartographically bounded entity, but as a series of spiritually potent toponyms. The space between one point and another on such list maps was marked by movement - missions and visitations, homages and petitions - by the traffic of individuals bearing goods, government decrees, offerings, donations or complaints. This

70 AOM INDO, GGI 65502, RSC 'Rapport politique 1922, $3^{\text {ième }}$ trimestre'; 'Chemins de fer royaux du Siam', Extrême-Asie, 42 (1929), advertising supplement, p. 1.

71 AOM INDO, GGI 65547, RSC 'Rapport politique’, 13 July 1932.

72 AOM FM INDO, NF 577, RSC confidential report to GGI, No.499-SPX, 'Voyage de S.M. Monivong dans les provinces de son Royaume', 18 July 1933.

73 AOM FM INDO, NF 577, Marius Moutet to Direction des Affaires Politiques, Minister of Colonies, Note No. 932, 25 June 1936. Recollections of the incident were provided by Nou Hach's widow Rem Tan and son Vinit Nou, interviewed together with his son Voravid Nou, Sydney, 3 Mar. 1998. See also 'Une irréparable faute politique', Le Khmer, 18 May 1936.

74 'Cambodge: Le Vice-Amiral d'Escadre Decoux GGI rend visite au nouveau souverain,' L'avenir du Tonkin, 5 June 1941.

75 Maurice Ducoroy, Ma trahison en Indochine (Paris: Éditions Inter-Nationales, 1949), p. 119; see also Christopher Goscha, Vietnam or Indochina? Contesting concepts of space in Vietnamese nationalism 18871954 (Copenhagen: Nordic Institute of Asian Studies, 1995), p. 80. 
was not unidirectional: peasants would petition the Crown, ministers would visit outlying districts, and Theravada Southeast Asia's network of peripatetic monks and lay worshippers travelled between holy sites in Burma, Siam, Laos, and Cambodia. ${ }^{76}$ The list maps described by Chandler bear parallels with the medieval European maps described by Michel de Certeau and, like the latter, contrast with the 'totalizing stage' of the modern map. In Cambodia as elsewhere, the colour-coded plateau of modern cartography introduced new ways not only of relating to one's own territory but of visualizing and compartmentalizing the peoples who had long lived in surrounding regions. ${ }^{77}$ Although one might imagine, like the American poet Elizabeth Bishop, that 'topography displays no favourites', modern techniques of colour-coding lent ready form to notions of favoured races converting those slabs outside of Cambodia's colonial borders into its cartographic Others. ${ }^{78}$

The new European-style maps were not just hung in colonial offices, they were also used to nudge notions of Buddhist cosmography from local mindsets through the introduction of maps into vat (temple) schools. In 1919, Minister of War and Education Ponn Chakrey requested 15 of the 'newly printed, large Khmer-language maps of Cambodia which show the mountains and all zones (damboun), provinces and khum' as teaching aids to repalce the 'little maps' then being used for geography lessons in Phnom Penh's temple schools. Khmer-language 'physical and political maps of Cambodia' were duly supplied by the Ministry of Public Education. ${ }^{79}$ Meanwhile, in the Metropole, the heightened political nationalism of interwar Europe triggered a resurgence in interest in 'national' geography. 'We are definitely not a race but a nation', declared the right-wing intellectual Maurice Barrès in 1925, asserting that 'everything we are arises from the historical and geographical conditions of our country' ${ }^{80}$

The constant tinkering with boundaries and administrative systems made a chameleon of such national geography in the colonies, where maps constantly needed updating and revising not only to reflect the accumulation of knowledge about the 'intérieur', but also to record the administrative restructuring and physical extension of Cambodia. The introduction of geography lessons into secular and vat school curricula in the early twentieth century furnished Cambodia's educated elite with a conceptual framework for these spatial adjustments and territorial alignments. By the late 1930s, the first wave of urban-educated nationalists had adopted these concepts; they brandished the map as a sacrament of nation and condemned officials who still clung to regional identities at the expense of national loyalties. ${ }^{81}$

76 Anthony Reid, 'A saucer model of Southeast Asian identity', Southeast Asian Journal of Social Science, 27, 1 (1999): 12.

77 Michel de Certeau, The practice of everyday life, tr. Steven Randall (Berkeley: University of California Press, 1984), p. 121. Here as elsewhere my thoughts are inspired by Thongchai Winichakul's Siam mapped: A history of the geobody of a nation (Honolulu: University of Hawaii Press, 1994).

78 Meron Benvenisti, Sacred landscape: The buried history of the Holy Land since 1948, tr. Maxine Kaufman-Lacusta (Berkeley: University of California Press, 2002), p. 55.

79 AOM, INDO, RSC 466, Letter from Ponn Chakrey to RSC, 29 Jan. 1919 and Note from RSC to Ponn Chakry, Nov. 1919.

80 Maurice Barrès, Scènes et doctrines du nationalisme, tome I (Paris: Plon Nourrit, 1925), pp. 20, 114.

81 See, for example, 'Driw loap Krong Kampbujie cenbi knong paenday look ceen ru away?' [Must Cambodia be deleted from the map of the world?]; and 'Kmae oubbchnamdachay men prum cen chngai bi pteah kluen' [Khmers refuse to go far from their homes], Nagaravatta, 19 Nov. 1938 and 18 May 1940 respectively. 
While the colonial construct of Cambodia gained a 'reality effect' from such representations, 'Indochina' remained an abstraction for the average Cambodian, who lacked practical experience of this greater colonial space..$^{82}$ In the Khmer newspaper Nagaravatta and other forums, Tonkin, Annam and Cochinchina were still commonly lumped together as simply 'Yuon-country' (Nokor Yuon or Srok Yuon), a term emphasizing not geographic integration but racial differentiation. ${ }^{83}$ This plural vocabulary indicated a parallel, colonial geography whose vocabulary - the empty phonetic In-do-sin - did not replace, but simply glossed over indigenous cosmologies. ${ }^{84}$

Benedict Anderson has noted how the career paths of colonial functionaries engineered the 'subtle, half-concealed transformation, step by step, of the colonial-state into the national-state, a transformation made possible not only by a solid continuity of personnel, but by the established skein of journeys through which each state was experienced by its functionaries' ${ }^{85}$ Yet where Vietnamese bureaucrats tended to relate to the larger construct of 'Indochine', anecdotal evidence suggests that travel in In-do-sin and out of 'Cambodia' by Cambodians, or out of Cochinchina and to Cambodia by Khmer Kraom, encouraged a reverse pattern of identification, exaggerating external expressions of Khmerness. Thus, the future Cambodian Prime Minister Lon Nol, attending lower secondary school (collège) in Saigon in the 1930s, apparently insisted on wearing a chequered sampot (sarong) instead of the standard-issue white colonial uniform, as a demonstration of difference.

The roads Cambodian nationalists travelled from the 1920s to the 1940s may have included Saigon, Hanoi and Paris, but the national habitus they mapped in their writings was a Khmer-centric, and not an Indochina-wide, cosmos. In a reversion to, or echo of, the Cochinchina-centric itineraries of French and Cambodian administrators at the turn of the century, outings organized by youth groups brought ethnic Khmers from Cochinchina to Cambodia, and vice versa. These territorially elastic, ethnocentric configurations of nationality would present a lasting challenge to the Indochina wide paradigms and accompanying visions of federation embraced by some contemporary Vietnamese nationalists. ${ }^{86}$

\section{Conclusion}

Colonial modalities of organizing, representing and naming space in the Protectorate of Cambodge supplemented rather than suppressed indigenous conceptions. Like the Gregorian dates that twinned the Buddhist Era calendar in Khmer publications and like

82 Edward Brown, Cochin-China and my experience of it: A seaman's narrative of his adventures and sufferings during a captivity among Chinese pirates and afterwards during a journey on foot across that country in the years 1857-58 (London: Charles Westerton, 1861), p. 20. Albert Bouinais and A. Paulus, L'IndoChine Française contemporaine: Cochinchine, Cambodge, Tonkin, Annam (Paris: Challamel Ainé, 1885), pp. 574-5; De la Brosse, 'Territoire de Battambang: Notes économiques', p. 1329.

83 See, for example, the Tonkin travelogue 'Bi Krong Kampujie tiw dal Tongking' [From Cambodia to Tonkin], Nagaravatta, 17 July 1940.

84 Benedict Anderson, Imagined communities: Reflections on the origins and spread of nationalism, 2nd edn (New York: Verso, 1991), pp. 129-30.

85 Ibid., p. 114. For more on this, see Edwards, 'Cambodge'.

86 Christopher Goscha, 'Beyond the colonizer and the colonized', in Songs at the edge of the forest: New reflections on Khmer Studies, ed. Judy Ledgerwood and Anne Hansen, forthcoming. The information on the student trips is from NAC 12443, 'Excursion of Khmer students from Soctrang to Cambodge', 27 Mar. 1937. I am grateful to the late Ingrid Muan for sending me her notes from this document in July 2000. 
the linear history of Angkor plotted by European scholars, which gained currency but never entirely displaced oral histories, colonial communication routes existed alongside and in some cases astride old pathways. Sacred trees, old place names and other monuments to a non-colonial time and place were landmarks of covert and subversive traffic, from monks crossing over to Siam in the 1910s and 1920s or Cao Đài faithful flocking to Cochinchina in the 1920s and 1930s. From the 1920s to the 1940s, this overlaying of new roads on old spirit paths saw acts of anger and automobile accidents attributed to neak ta (tutelary gods). ${ }^{87}$

In this respect, the routes charted and laid under the Protectorate were the built equivalent of the utopian blueprints identified by Ann Stoler in her recent work on Dutch colonial archives. Noting the disjuncture between policies drafted on paper and what was actually implemented, Stoler reads these archives as diagnostic of 'deep anxieties about a Dutch national past and of an Indies colonial future, of a colonial utopia obliquely expressed' ${ }^{88}$ In their material glory, roads served as indisputable symbols of modernity and of European power: built under duress, they scarred the landscape - and some lives - irreversibly. However, the directions the human traffic on those roads took, and the destinies they delivered to Europeans such as the hapless Bardez and Jean Commaille (the first Curator of Angkor from the École Française d'Extrême-Orient, murdered in 1916), depended on a factor beyond European control: public sentiment.

After Independence, from 1954 to 1970, Norodom Sihanouk honed the royal tour to fine political theatre, and marked the iconography of Angkor on vehicles of travel, with the National Angkor Tyre Company and the Angkorean logo of the Royal Khmer Railways. Visiting Cambodia in the late 1950s, the English travel writer Christopher Pym found the trains popular with monks, who travelled half-price. Accompanying a novice from Phnom Penh to his ordination ceremony in Battambang, Pym detected a public pride in the Royal Khmer Railways, but also noted wryly the way in which the tracks were used as gathering places by villagers seeking refuge from flooded terrain in the rainy season - behaviour that resulted in a Royal Circular reminding the public that the 'roads and pavements are reserved exclusively for traffic and are not places of rest'. Arriving later by boat at the riverside temple Wat Daing Ngea northwest of Battambang, Pym and his friend found a sala close to the bank, its roof supported by 22 pillars, and the temple set further back. ${ }^{89}$

However, as in the colonial period, this investment in the railway network did not translate into enhanced mobility for all; Sihanouk's regime and others that followed continued to regulate the mobility of the populace through systems of carding. With the expansion of the Vietnam War (particularly US bombing) into Cambodia, the phenomenon of refugee flight, last seen on a much smaller scale in 1885-86, resumed, and Phnom Penh's population swelled to over a million. From 1975-79, Pol Pot's Democratic Kampuchea regime exerted an unprecedented control over popular mobility through the

87 Alain Forest, Le culte des génies protecteurs au Cambodge: Analyse et traduction d'un corpus de textes sur les neak ta (Paris: L'Harmattan, 1992).

88 Ann Stoler, 'Developing historical negatives: Race and the (modernist) visions of a colonial state', in From the margins: Historical anthropology and its futures, ed. Brian Axel (Durham and London: Duke University Press, 2002), p. 157.

89 Christopher Pym, Mistapim in Cambodia (London: Charing Cross Book Club, 1960), pp. 72-5. 
emptying of the capital and the forced dispersal of 'new' people from the cities to the countryside. Despite its rejection of modern technology, often symbolized by Western media depictions in the 1980s of abandoned cars in the capital, the DK regime maintained a railway system and relied on roads to transport both its cadres and their victims, possibly seeing the railways as an emblem of the high modernity and velocity that they at once repudiated and strived towards in their attempt to achieve the fastest revolution in the world..$^{90}$ After Pol Pot was toppled, the successor regime, supported by Vietnamese troops, restricted the movements of displaced people back into Phnom Penh and provincial capitals. In 1980s Cambodia, the need for written permission from authorities for individual travel, the corralling of mass sections of the population for forced labour projects on the Thai-Cambodian border under the notorious K-5 programme, and the choreography of mass rallies, all evidenced control of mobility. ${ }^{91}$

As Caroline Hughes and Eve Zucker point out in their essays for this journal issue, controls of mobility and the linkage of the provision of roads to political patronage are continuing features of Cambodia. In the anti-Thai riots studied by Alexander Hinton in his article, motorbikes afforded rapid mobility, and decisions at the highest levels within Cambodian power structures to keep extra police off the streets at a critical juncture gave these highly mobile protesters a speedway to destruction. More recently, the burning of car tyres has become a new form of protest at rising fuel prices and arbitrary traffic taxes. In 2004, in the continuing absence of a fair and functioning judiciary, people continue to travel well-tried routes to justice, along new and improved roads from the provinces to the capital, seeking audiences with the king or engaging in sit-down protests outside of Premier Hun Sen's residence near the Independence Monument in Phnom Penh. Rapid urbanization has also encouraged new rural-urban migrations. However, as witness the ritual truck-stop en route from Phnom Penh to Kompong Saom where drivers seek a purchase on road safety through offerings to the resident and powerful neak ta Yiyiey Mau, there is more than human cargo plying Cambodia's new roads.

90 Stephen Heder, personal communication, Oct. 2002.

91 See Margaret Slocomb, 'The K5 gamble: National defence and nation building under the People's Republic of Kampuchea', Journal of Southeast Asian Studies, 32, 2 (2001): 195-210. 